\title{
水稲用除草剂「メタゾスルフロン」の開発
}

\author{
佐 伯 学 ${ }^{1}$, 矢 野哲 彦 ${ }^{1}$, 中屋潔 彦 ${ }^{2, *}$, 玉田 佳 ${ }^{3}$ \\ ${ }^{1}$ 日産化学工業株式会社農業化学品事業部 \\ ${ }^{2}$ 日産化学工業株式会社物質科学研究所 \\ ${ }^{3}$ 日産化学工業株式会社小野田工場
}

（2016年6月 10 日受理）

\section{Development of a novel herbicide, metazosulfuron}

\author{
Manabu SAekI, ${ }^{1}$ Tetsuhiko YAno, ${ }^{1}$ Yoshihiko NAKaYA ${ }^{2}$ and Yoshitake Tamada ${ }^{3}$ \\ ${ }^{1}$ Agricultural Division, Nissan Chemical Industries, Ltd., 3-7-1 Kanda Nishiki-cho, Chiyoda-ku, Tokyo 101-0054, Japan \\ ${ }^{2}$ Chemical Research Laboratories, Nissan Chemical Industries, Ltd., 2-10-1 Tsuboi-Nishi, Funabashi, Chiba 274-8507, Japan \\ ${ }^{3}$ Onoda Plant, Nissan Chemical Industries, Ltd., 6903-1 Oaza Onoda, Sanyo-Onoda, Yamaguchi 756-0096, Japan
}

Keywords: metazosulfuron, herbicide, pyrazolesulfonylurea, ALS.

\section{は じめに}

メタゾスルフロンは，日産化学工業株式会社が見出した 新規水稲用スルホニルウレア系除草剂であり，60１20 g a.i./ haの処理薬量でノビエを含む各種一年生雑草および多年生 雑草，さらに近年問題となっているスルホニルウレア抵抗性 雑草に対しても優れた除草効果を発揮する。また，メタゾス ルフロンは水稲に対する安全性に優れ，哺乳動物や各種環境 生物に対して高い安全性を有することも確認されている。メ

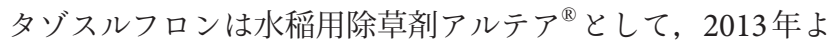
り日本国内での販売を開始しており，一発処理除草剂および 中後期除草剂として本剂を配合した各種混合剂を製品化して いる.また，海外での開発も進めており，韓国および中国で 農薬登録を取得し，販売を開始している。

本稿では, リード化合物の発見からメタゾスルフロン創出 に至る研究経緯, メタゾスルフロンの除草特性をはじめとす

\footnotetext{
* = 274-8507千葉県船橋市坪井西 2-10-1

E-mail: nakayayo@nissanchem.co.jp

(c) 日本農薬学会
}

る生物活性について報告する。

\section{1. 研 究 の 経 緯}

\section{1. リード化合物の選抜}

スルホニルウレア系除草剤はアセト乳酸合成酔素（ALS） 阻害剂のひとつで，分岐鎖アミノ酸生合成系に関わるALS を阻害することで除草活性を発現する. ALS は植物および微 生物に特有の酵素であることから, ALSをもたない動物に対 する安全性はきわめて高い。また，低薬量で雑草を防除でき る，殺草スペクトラムが広いなど，優れた性能を有している ことから，スルホニルウレア系除草剂はその登場以来 30 年 以上にわたって使用され続けている化合物群であり, 現在も なお世界の作物生産に不可欠な除草剂である。国内では各種 スルホニルウレア系除草剂が水稲用除草剂として広く利用さ れてきたが，多用された結果，1990年代半ばからスルホニ ルウレア抵抗性雑草が確認されるようになった。2000年代 に入ると全国的に報告されるようになり，これらの防除が水 稲栽培における問題として顕在化していた。そこで, 我々は スルホニルウレア抵抗性雑草を含む幅広い殺草スペクトラム と水稲安全性をあわせもった新たな水稲用除草剤の創出を目 
<smiles>CCOC(=O)c1cnn(C)c1SNC(=O)Nc1nc(OC)cc(OC)n1</smiles>

pyrazosulfuron-ethyl<smiles>COc1cc(OC)nc(NC(=O)NSc2c(C(=O)O)c(Cl)nn2C)n1</smiles>

halosulfuron-methyl

Fig. 1. Pyrazolesulfonylurea herbicides developed by Nissan Chemical Industries, Ltd.

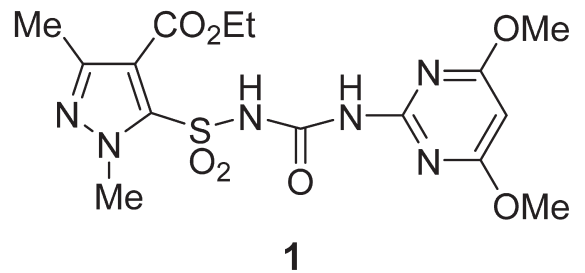

Fig. 2. The lead compound selected from the sulfonylurea library.

指して, 創製研究を開始した.

当社ではALS阻害剤であるピラゾスルフロンエチル，八 ロスルフロンメチルを製品化しているが（Fig. 1)，これらに 対するスルホニルウレア抵抗性雑草の感受性低下は比較的少 ないことが知られていたことから ${ }^{1-3)}$ ，当社が保有するスル ホニルウレアライブラリーについて, 抵抗性雑草に対する除 草活性抢よび水稲に対する安全性といった観点で再評価を 行った. その結果, 当社スルホニルウレアの化学構造上の特 徵であるピラゾール環上5位にスルホニルウレアユニットを 有する化合物が除草活性および水稲安全性の両面で良好であ り，なかでも化合物 1 が水稲安全性は不十分ながらスルホニ ルウレア抵抗性雑草に対して高い除草活性を示すことを見 出した (Fig. 2) $)^{4)}$. そこで, 化合物 1 をリード化合物として, 合成展開を開始することとした。

\section{2. メタゾスルフロンの創出}

化合物 1 とピラゾスルフロンエチルの化学構造上の違いは ピラゾール環上 3 位メチル基の有無のみであることから，ピ ラゾール環上の置換基がスルホニルウレア抵抗性雑草に対す る除草活性に大きく影響するものと考え，その变換に注力す ることとした。

ピラゾール環上の置換基として，1位はメチル基，3位は メチル基，クロロ基および無置換の場合に除草活性が優れ, その他の変換では活性が低下した。 また，ピラゾール環上 4 位の変換では, 種々の鎖状置換基を導入したものの, 除草 活性および水稲安全性で化合物 $\mathbf{1}$ を上回る化合物を見出せな かった.

そこで，新たな展開としてピラゾール環上 4 位への環構造 の導入を試みることとした，その過程で，イソオキサゾリン
環を導入した化合物 2 を合成, 生物評価したところ, 除草活 性は実用レベルに達していなかったものの，水稲に対する 安全性が化合物 1 と比べて改善したことから ${ }^{5)}$ ，4位に種々 のへテロ環を導入することとした，そのなかで，ジオキサジ ン環を導入した化合物 3 に大幅な除草活性の向上が認められ たことから，化合物 $\mathbf{3}$ を心とした詳細な構造最適化を行っ た（Fig. 3)。その結果，ピラゾール環上 1 位にメチル基， 3 位にクロロ基, ジオキサジン環上 5 位にメチル基を有する化 合物, すなわちメタゾスルフロンが除草効果, 殺草スペクト ラムおよび水稲安全性のいずれにおいても最良であることが 明らかとなった $(\text { Table 1) })^{6}$. なお，構造を最適化する上で, N-アリルオキシアミド化合物を環化前駆体とした八ロ環化 反応およびN-(2-ヒドロキシエトキシ) アミド化合物を環化 前駆体とした脱水環化反応を利用することで, 種々のジオキ サジン化合物を合成することが可能となった (Fig. 4) $)^{7)}$.

\section{2. 化合物の名称および物理化学的性質}

メタゾスルフロンの物理的化学的性質を Table 2 に示した. メタゾスルフロンは比較的水溶解度が高く, 処理後田面水中 に拡散しやすい特徴を有していることから，散布ムラなどに よる除草効果の変動が起こりにくいものと考えられた.

\section{3. 生 物 活 性}

\section{1. 除草活性}

メタゾスルフロンの除草活性を Fig. 5 に示した.メタゾス ルフロンは，60〜120ga.i./haの処理薬量でノビエを含む各 種一年生雑草に加えて, クログワイ, ミズガヤツリ，コウキ ヤガラなどの多年生雑草に対しても高い除草活性を示し，幅 広い殺草スペクトラムを有することが確認された。さらに， 近年問題となっているスルホニルウレア抵抗性雑草に対して も除草効果が高く，イヌホタルイやコナギ，ミズアオイ，才 モダカなど種々のスルホニルウレア抵抗性雑草を有効に防除 できることがわかった ${ }^{8,9)}$.

\section{2. 多年生カヤツリグサ科雑草に対する除草効果}

クログワイやシズイ，コウキヤガラといった多年生カヤツ リグサ科雑草は，塊茎からの発生が長期にわたることや発生 深度が深いことなどから, 水田雑草のなかでも防除が困難な 


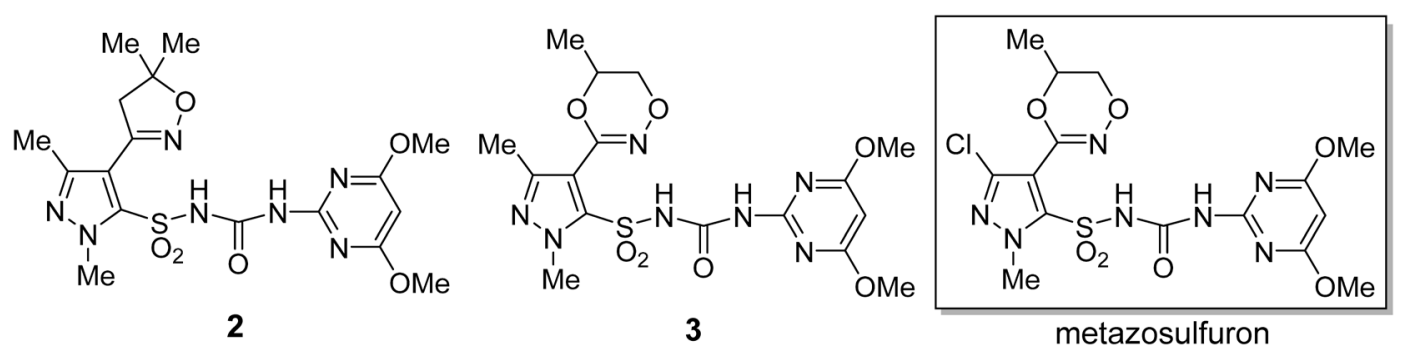

Fig. 3. Pyrazolesulfonylurea derivatives having heterocycle moiety at 4-position of pyrazole ring.

Table 1. Pre-emergence herbicidal activities of pyrazolesulfonylurea derivatives<smiles>[X][Z]1nc(NC(=O)NSc2c(C3=NOC([R7])C([R7])([R])O3)c([R])nn2C)nc1[Y]</smiles>

\begin{tabular}{|c|c|c|c|c|c|c|c|c|c|c|}
\hline \multirow{2}{*}{$\mathrm{R}^{3}$} & \multirow{2}{*}{$\mathrm{R}^{\mathrm{a}}$} & \multirow{2}{*}{$\mathrm{R}^{\mathrm{a}^{\prime}}$} & \multirow{2}{*}{$\mathrm{R}^{\mathrm{b}}$} & \multirow{2}{*}{$\mathrm{X}$} & \multirow{2}{*}{$\mathrm{Y}$} & \multirow{2}{*}{$\mathrm{Z}$} & \multicolumn{4}{|c|}{ Activity $^{\mathrm{a}, \mathrm{b})}$} \\
\hline & & & & & & & $A^{c)}$ & $B^{c)}$ & $\mathrm{C}^{\mathrm{c})}$ & $a^{c)}$ \\
\hline $\mathrm{Cl}$ & $\mathrm{Me}$ & $\mathrm{H}$ & $\mathrm{H}$ & $\mathrm{OMe}$ & $\mathrm{OMe}$ & $\mathrm{CH}$ & 5 & 5 & 5 & 0 \\
\hline $\mathrm{Me}$ & $\mathrm{Me}$ & $\mathrm{H}$ & $\mathrm{H}$ & $\mathrm{OMe}$ & $\mathrm{OMe}$ & $\mathrm{CH}$ & 5 & 5 & 5 & 3 \\
\hline $\mathrm{H}$ & $\mathrm{Me}$ & $\mathrm{H}$ & $\mathrm{H}$ & $\mathrm{OMe}$ & $\mathrm{OMe}$ & $\mathrm{CH}$ & 5 & 5 & 5 & 3 \\
\hline $\mathrm{Cl}$ & $\mathrm{Me}$ & $\mathrm{Me}$ & $\mathrm{H}$ & $\mathrm{OMe}$ & $\mathrm{OMe}$ & $\mathrm{CH}$ & 5 & 5 & 5 & 0 \\
\hline $\mathrm{Cl}$ & $\mathrm{H}$ & $\mathrm{H}$ & $\mathrm{Me}$ & $\mathrm{OMe}$ & $\mathrm{OMe}$ & $\mathrm{CH}$ & 5 & 5 & 5 & 0 \\
\hline $\mathrm{Cl}$ & Et & $\mathrm{H}$ & $\mathrm{H}$ & $\mathrm{OMe}$ & $\mathrm{OMe}$ & $\mathrm{CH}$ & 4 & 5 & 5 & 0 \\
\hline $\mathrm{Cl}$ & $\mathrm{Me}$ & $\mathrm{H}$ & $\mathrm{H}$ & $\mathrm{Me}$ & $\mathrm{OMe}$ & $\mathrm{CH}$ & 4 & 5 & 5 & 1 \\
\hline $\mathrm{Cl}$ & $\mathrm{Me}$ & $\mathrm{H}$ & $\mathrm{H}$ & $\mathrm{Cl}$ & $\mathrm{OMe}$ & $\mathrm{CH}$ & 3 & 5 & 5 & 0 \\
\hline $\mathrm{Cl}$ & $\mathrm{Me}$ & $\mathrm{H}$ & $\mathrm{H}$ & $\mathrm{OMe}$ & $\mathrm{OMe}$ & $\mathrm{N}$ & 0 & 0 & 0 & 0 \\
\hline
\end{tabular}

a) The dose of each compound was 64 ga.i./ha. ${ }^{\text {b) }}$ Herbicidal activities were visually evaluated using a scale of 0 (no effect) to 5 (completely with-

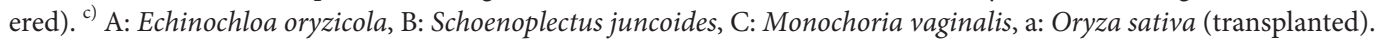

雑草として挙げることができる.メタゾスルフロンは水田雑 草に対して幅広い殺草スペクトラムを有しており, 特に多年 生雑草に対する除草効果に優れることから (Fig. 6), 難防除 雑草である多年生カヤツリグサ科雑草に対する効果について 詳細に検討した。その結果，メタゾスルフロンは，クログワ イやシズイ, コウキヤガラの塊茎産生（Figs. 7, 8) や分株形 成（Fig. 9）を抑制する効果に優れており，これらの雑草の 圃場内密度を低下させるのに有効な薬剤であると考えられ $た^{10,11)}$.

\section{3. 水稲安全性}

これまでに実施してきた温室試験および圃場試験よ り, 雑草を有効に防除しうる処理薬量において, メタゾス ルフロンが水稲の生育に影響をおよぼすことはきわめて
少ない。2006年から2009年にかけて実施した委託試験の 結果を Fig. 10 に示した.メタゾスルフロン+ダイムロン （100 g+1000ga.i./ha）は，水稲移植後5～10日，11〜 15日， 16〜20日のいずれの処理時期においても，水稲に対する安 全性が問題となることはほとんどないことが確認された。こ のことから, メタゾスルフロンの水稲安全性は非常に高く, 水稲と雑草間で高度な選択性を有することが明らかとなっ た。

\section{4. 作 用 機 作}

各種植物から抽出したALSに対するメタゾスルフロンの 酵素阻害活性を試験したところ, 従来のスルホニルウレア系 除草剂と同様にALSを強く阻害しており，これがメタゾス ルフロンの一次作用点であると推定した。メタゾスルフロン 


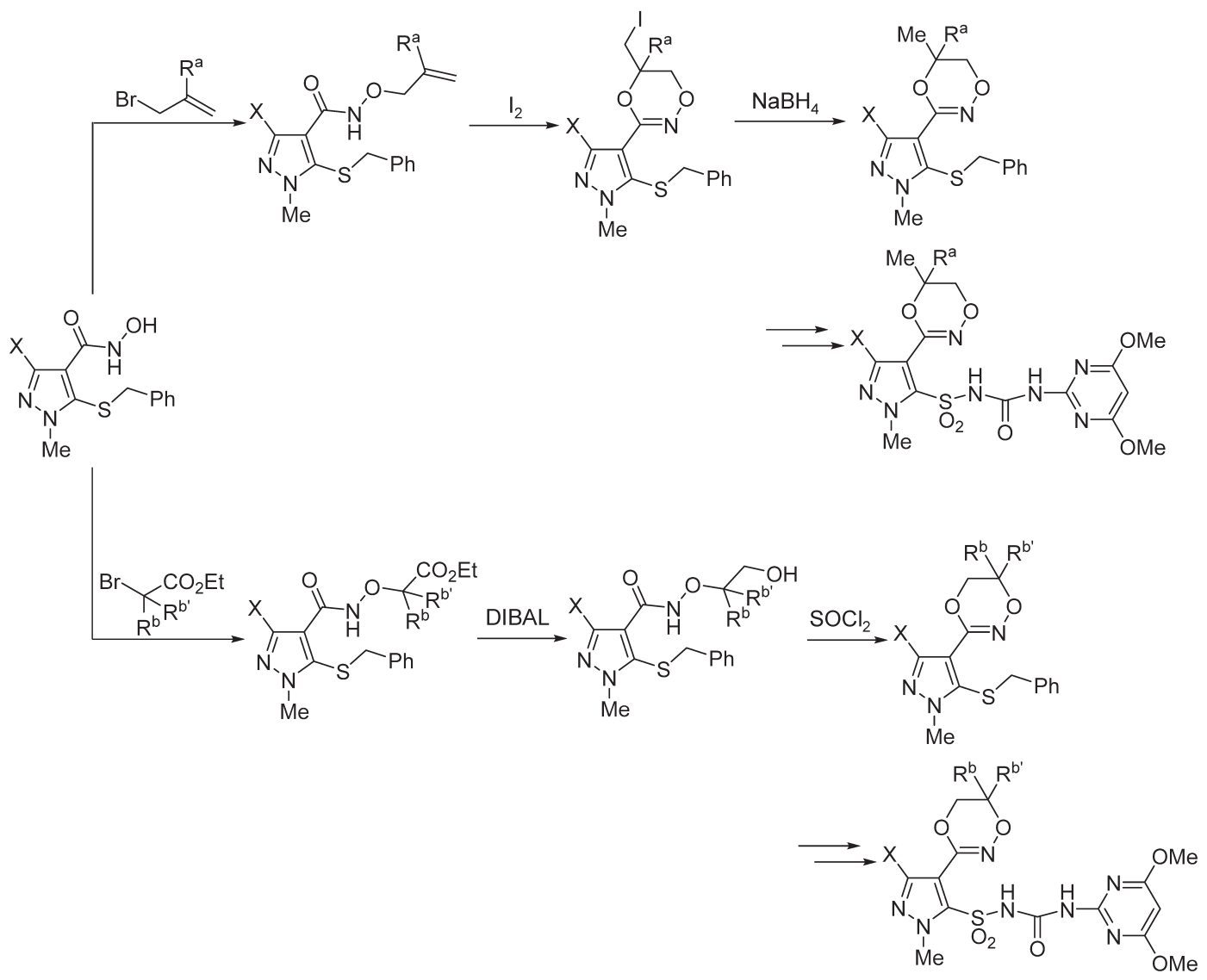

Fig. 4. Syntheses of dioxazine derivatives.

Table 2. Physical chemistry of metazosulfuron

$\begin{array}{ll}\text { ISO name } & \text { metazosulfuron } \\ \text { Chemical name (IUPAC) } & \begin{array}{l}\text { 1-\{3-chloro-1-methyl-4-[(5RS)-5,6- } \\ \text { dihydro-5-methyl-1,4,2-dioxazin- } \\ \text { 3-yl]pyrazol-5-ylsulfonyl }\}-3-(4,6-\end{array} \\ & \text { dimethoxypyrimidin-2-yl)urea } \\ & \text { NC-620 } \\ \text { Development code } & 868680-84-6 \\ \text { CAS No. } & \mathrm{C}_{15} \mathrm{H}_{18} \mathrm{ClN}_{7} \mathrm{O}_{7} \mathrm{~S} \\ \text { Molecular formula } & 475.86 \\ \text { Molecular weight } & \text { White solid, odorless } \\ \text { Appearance } & 1.49 \mathrm{~g} / \mathrm{cm}^{3} \\ \text { Density } & 175.5-177.6^{\circ} \mathrm{C} \\ \text { Melting point } & 33.3 \mathrm{mg} / \mathrm{L}\left(\mathrm{in} \mathrm{water}, 20^{\circ} \mathrm{C}\right) \\ \text { Solubility } & 7.0 \times 10^{-8} \mathrm{~Pa}\left(25^{\circ} \mathrm{C}\right) \\ \text { Vapor pressure } & 3.4\left(20^{\circ} \mathrm{C}\right) \\ \text { pK } & 1.87\left(25^{\circ} \mathrm{C}, \mathrm{pH} 4\right) \\ \text { log } P_{\text {ow }} & -0.35\left(25^{\circ} \mathrm{C}, \mathrm{pH} 7\right) \\ & -0.58\left(25^{\circ} \mathrm{C}, \mathrm{pH} \mathrm{9)}\right. \\ & \end{array}$

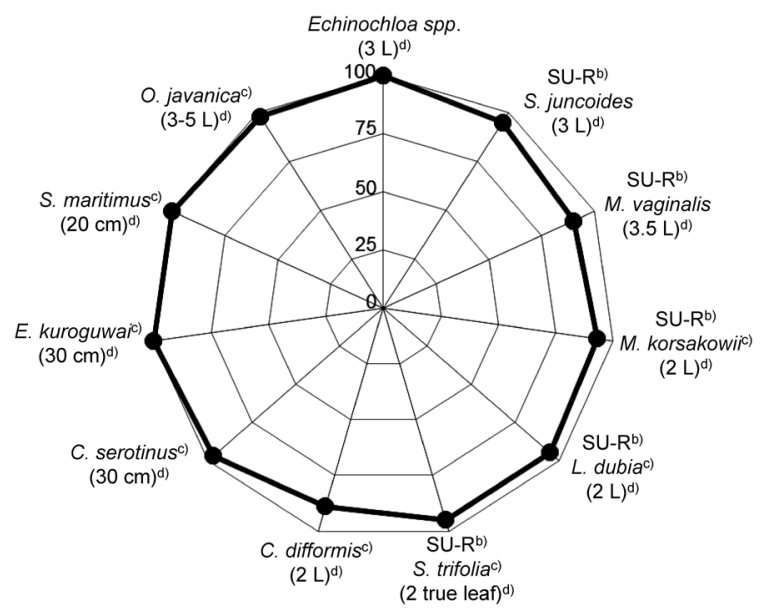

Fig. 5. Herbicidal efficacy of metazosulfuron ( $100 \mathrm{~g}$ a.i./ha) on major paddy weeds. . $^{\text {a }}$

a) Weed controls were visually evaluated using a scale of 0 (no effect) to 100 (completely withered). ${ }^{\text {b) }}$ SU-R:sulfonylurea resistant. c) M. korsakowii: Monochoria korsakowii, L. dubia: Lindernia dubia, S. trifolia: Sagittaria trifolia, C. difformis: Cyperus difformis, C. serotinus: Cyperus serotinus, E. kuroguwai: Eleocharis kuroguwai, S. maritimus: Schoenoplectus maritimus, O. javanica: Oenanthe javanica. ${ }^{\mathrm{d})}$ The growth stage or size of each weed at application are shown in parentheses. 


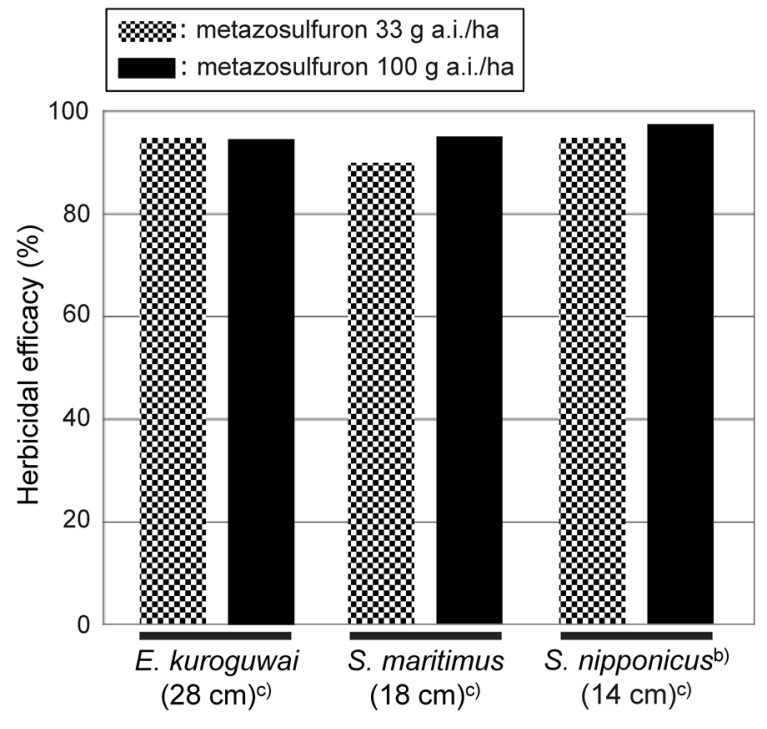

Fig. 6. Herbicidal activity of metazosulfuron against perennial Cyperaceous weeds. ${ }^{\text {a) }}$

a) Weed controls were visually evaluated using a scale of 0 (no effect) to 100 (completely withered) at 34-56 days after application. b) S. nipponicus: Schoenoplectus nipponicus. ${ }^{c}$ The shoot length of each weed at application are shown in parentheses.

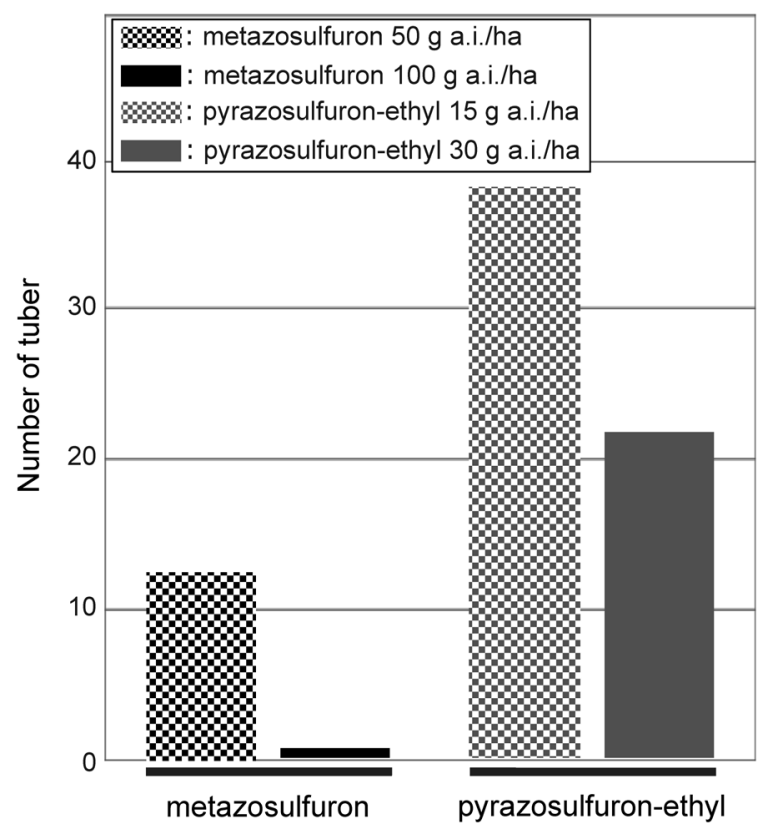

Fig. 7. Pre-emergence effect of metazosulfuron on tuberization of E. kuroguwai. ${ }^{\text {a) }}$

a) Number of tuber was counted at 96 days after transplanting.

\section{を処理された雑草は, 分岐鎖アミノ酸の生合成が阻害され} た結果，枯死に至るものと考えている。また，メタゾスルフ ロンは, ピラゾスルフロンエチルに抵抗性を示すオモダカの ALSも強く阻害し, 感受性オモダカのALSに対する酵素阻 害活性と同等であることを確認した (Fig. 11) ${ }^{12}$.

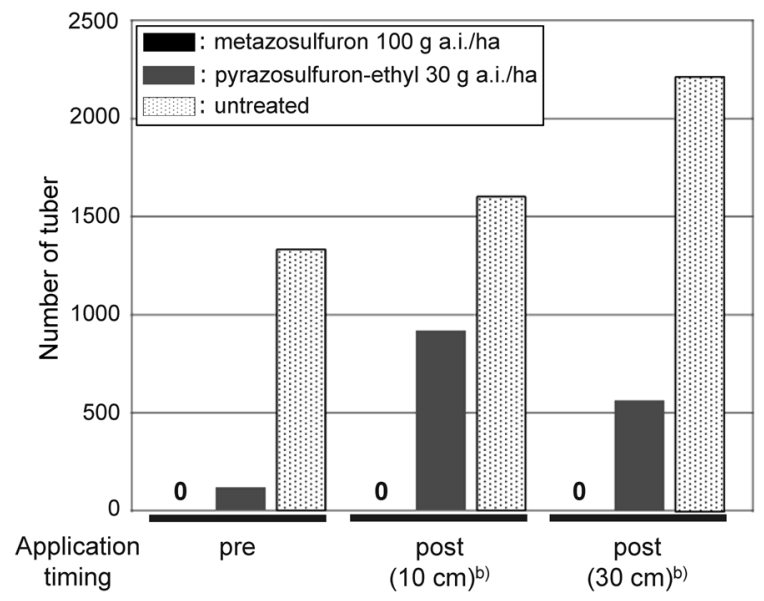

Fig. 8. Effect of metazosulfuron on tuberization of S. nipponicus. ${ }^{\text {a) }}$

a) Number of tuber was counted at 154 days after transplanting. b) The shoot length of $S$. nipponicus at application are shown in parentheses.

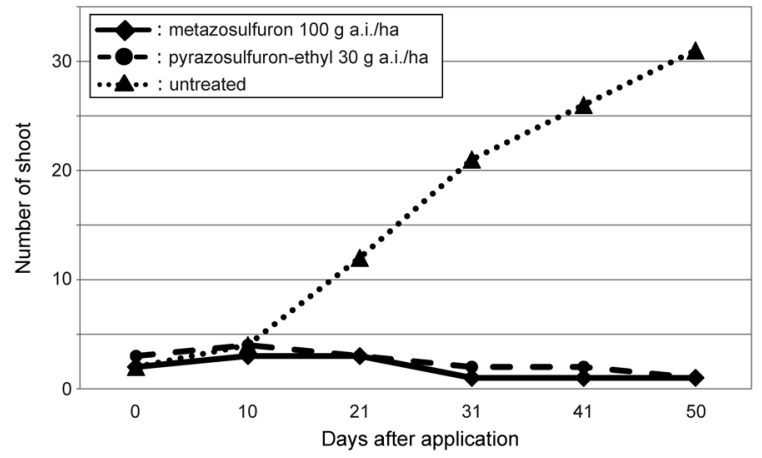

Fig. 9. Post-emergence effect of metazosulfuron on shoot number of S. maritimus. a)

a) The shoot length of $S$. maritimus at application was $30 \mathrm{~cm}$.

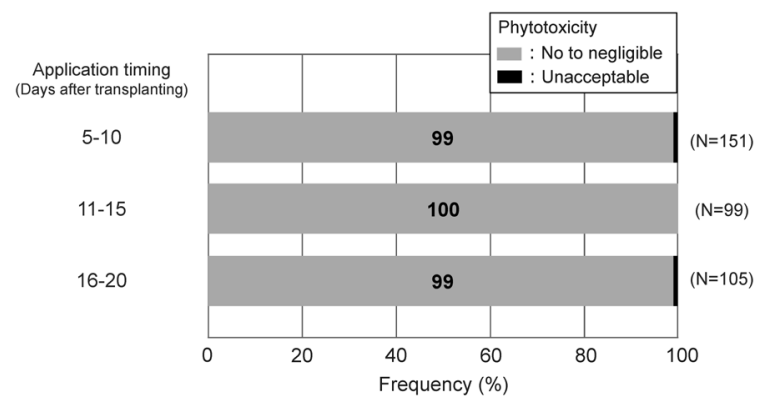

Fig. 10. Crop safety of metazosulfuron + daimuron $(100+1000 \mathrm{~g}$ a.i./ha) to transplanted rice (Summary of field trials by Japan Association for Advancement of Phyto-Regulators (JAPR) from 2006 to 2009).

\section{5. 安 全 性}

メタゾスルフロンの安全性試験結果をTable 3に示した. 

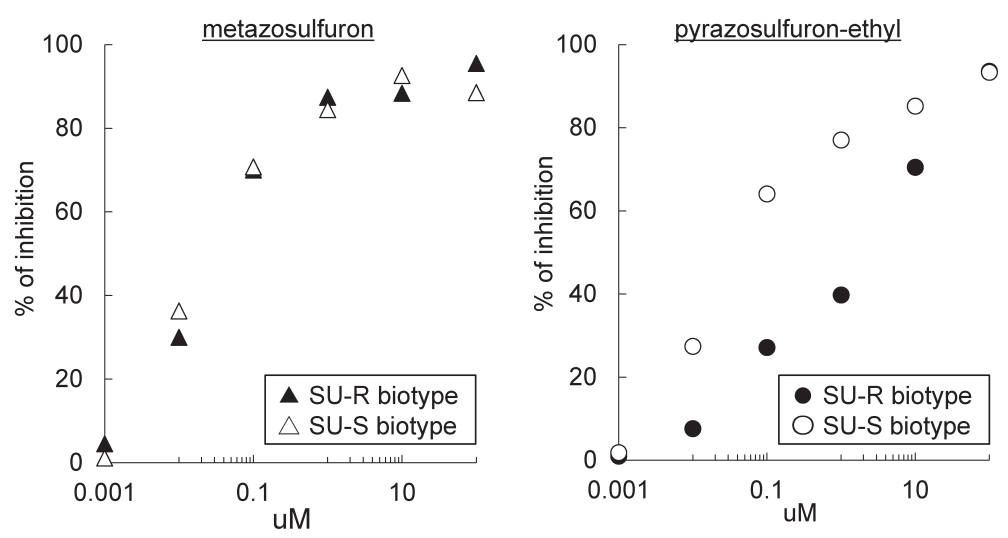

Fig. 11. Percent inhibition analyses of ALS extracted from sulfonylurea susceptible (SU-S) and resistant (SU-R) biotypes of S. trifolia of metazosulfuron and pyrazosulfuron-ethyl. ${ }^{\text {a) }}$

a) The ALS activity was measured according to the method of Westerfield (1945) with modifications. The SU-S S. trifolia biotype from Saitama Pref. and SU-R S. trifolia biotype from Iwate Pref. were grown in the greenhouse. The accumulation of acetoin was determined from the absorbance at $530 \mathrm{~nm}$ and the \% of ALS inhibition was calculated based on the acetoin accumulations.

Table 3. Toxicology and ecotoxicology of metazosulfuron

\begin{tabular}{lll}
\hline \multicolumn{1}{c}{ Study } & \multicolumn{1}{c}{ Organism } & \multicolumn{1}{c}{ Result } \\
\hline Acute oral & Rat & $\mathrm{LD}_{50}>2000 \mathrm{mg} / \mathrm{kg}$ \\
Acute dermal & Rat & $\mathrm{LD}_{50}>5.05 \mathrm{mg} / \mathrm{L}$ \\
Skin irritation & Rabbit & Non-irritant \\
Eye irritation & Rabbit & Minimal irritant \\
Mutagenicity & Ames tests & Negative \\
& Micronucleus tests & $\begin{array}{l}\text { Negative } \\
\text { Acute toxicity }\end{array}$ \\
& Carp & $\mathrm{LD}_{50}>95.1 \mathrm{mg} / \mathrm{L}$ \\
& Daphnia magna & $\mathrm{EC}_{50}>101 \mathrm{mg} / \mathrm{L}$ \\
Ecotoxicity & Apis mellifera & $\mathrm{LD}_{50}>100 \mu \mathrm{g} / \mathrm{bee}$ \\
& & $\mathrm{Cr}, \mathrm{Contact})$ \\
& Bobwhite quail & $\mathrm{LD}_{50}>2000 \mathrm{mg} / \mathrm{kg}$ (Oral) \\
& Eisenia foetida & $\mathrm{LD}_{50}>1000 \mathrm{mg} / \mathrm{kg}$ \\
\hline
\end{tabular}

メタゾスルフロンは哺乳動物や各種環境生物に対して，きわ めて高い安全性を有することが確認された。

\section{6. おわり に}

メタゾスルフロンは2006年度より公的試験を開始し, , ビエを含む各種一年生雑草, 多年生雑草に対する効果および 水稲に対する高い安全性が評価された。メタゾスルフロンは 各種スルホニルウレア抵抗性雑草に対しても優れた除草効果 を有しており, 従来にはない特長をもった新しいスルホニル ウレア系除草剂である.さらに，クログワイやシズイ，コウ キヤガラといった難防除の多年生カヤツリグサ科雑草に対し ては，分株形成および塊茎産生を抑制することで地上部と地 下部の双方から除草効果を発揮することが明らかとなってい る.
メタゾスルフロンは2013年に新規水稲用除草剂アルテア ${ }^{\circledR}$ として日本国内での販売を開始し，これまでに本剤を配合し た一発処理除草剂としてッインスター ${ }^{\circledR}$, 月光 ${ }^{\circledR}$, 銀河 $^{\circledR}, コ$ メット ${ }^{\circledR}$ が 1 キロ粒剤・フロアブル剂・ジャンボ剤・顆粒剂 などの多彩な剂型で商品化され，水稲生産現場で使用されて いる。また，2016年より中後期除草剂としてゲパード ${ }^{\circledR}, レ$ ブラス ${ }^{\circledR}$ 販売している. 海外においては, 日本に先行して 2012年に韓国で，2015年には中国で販売を開始している.

メタゾスルフロンは, 合成および生物評価担当者の創意工 夫によって創りあげたユニークな除草剂であり，本剂を実用 化したことは研究開発に携わった関係者の緊密な連携と努力 の成果である. 今後もメタゾスルフロンが世界の水稲栽培の 発展に一層貢献できるよう, さらなる製品開発を進めていく.

最後に，メタゾスルフロンの開発・上市にあたり，ご指導 とご支援を賜りました公益財団法人日本植物調節剂研究協会, 国公立の指導・研究機関の先生方に厚くお礼申し上げます.

\section{引用 文 献}

1) B. S. Manley, B. K. Singh, D. L. Shaner and H. P. Wilson: Weed Technol. 13, 697-705 (1999).

2) Y. I. Kuk, H. I. Jung, O. D. Kwon, D. J. Lee, N. R. Burgos and J. O. Guh: Pest Manag. Sci. 59, 949-961 (2003).

3) Y. I. Kuk, O. D. Kwon, H. I. Jung, N. R. Burgos and J. O. Guh: Pestic. Biochem. Physiol. 74, 129-138 (2003).

4) 北 浩, 佐伯 学 (日産化学工業): 特開 2005-002029 (2005).

5) 北 浩, 玉田佳丈, 矢野哲彦, 佐伯 学 (日産化学工業) : 特開 2005-112840 (2005).

6) 北 浩, 玉田佳丈, 中屋潔彦, 矢野哲彦, 佐伯 学 (日産化学工 業)：特開2005-336175 (2005).

7) 中屋潔彦：ファインケミカル45, 44-49 (2016). 
8) 矢野哲彦, 佐伯 学, 小林 弘, 玉田佳丈, 中屋潔彦, 森本勝 之: 日本雑草学会第 51 回大会講演要旨集, p. 21, 2012.

9) T. Miyazaki, T. Yano, M. Saeki, H. Kobayashi, Y. Nakaya, Y. Tamada and K. Morimoto: Proc. 6th Int. Weed Sci. Congr., p. 47, 2012.

10）矢野哲彦, 遠藤利治, 宮崎隆雄, 石松 純, 鈴木宏一 : 日本雑草 学会第 52 回大会講演要旨集, p. 19, 2013.

11）石松 純, 宮崎隆雄, 矢野哲彦: 日本雑草学会第 53 回大会講演 要旨集, p. 33, 2014.

12) H. Kobayashi, K. Nakahira, M. Saeki, Y. Nakaya, Y. Tamada and K. Morimoto: 4th Pan Pac. Conf. Pestic. Sci., p. 49, 2008.

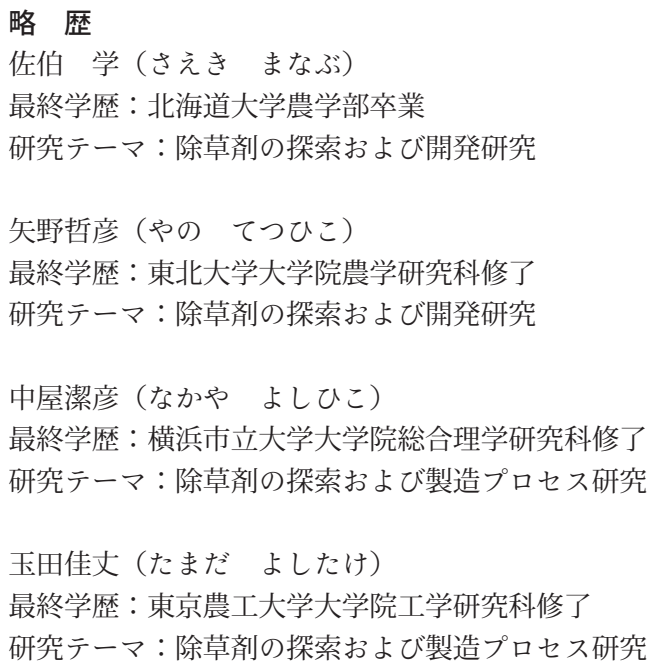

